\title{
METODY ROZWIAZZYWANIA KONFLIKTÓW W PRZEDSIĘBIORSTWIE A INTEGRACJA PRACOWNICZA
}

\section{WSTĘP}

Konflikty są nieuniknione we wszystkich przedsiębiorstwach. Są one najbardziej widocznym przejawem zakłócenia relacji interpersonalnych ${ }^{1}$. Konflikty wynikają z postrzeganej, a nie tylko obiektywnie istniejącej niezgodności. Wywołują one specyficzne zachowania wobec drugiej strony, którym na ogół towarzyszą silne emocje ${ }^{2}$. Z konfliktem w przedsiębiorstwie mamy do czynienia, gdy istnieją podmioty odmawiające współpracy w realizowaniu celów innych podmiotów. Wyznacznikiem konfliktu w szerszym znaczeniu tego słowa jest deklarowana w sposób otwarty lub też przybierająca formę apatii, nieudolności lub pozornego współdziałania odmowa współpracy. Podstawowym wyróżnikiem konfliktu w ujęciu wąskim są działania skierowane bezpośrednio przeciwko drugiej stronie, które mają doprowadzić do wyeliminowania rywala, przeszkadzającego zwykle w realizacji postawionych celów ${ }^{3}$.

Początkowo konflikt oceniano negatywnie i traktowano go jako rezultat nieprawidłowości natury indywidualnej lub społecznej. Dla określenia konfliktu zamiennie posługiwano się takimi wyrażeniami jak: przemoc, destrukcja,

${ }^{1}$ Zob. L. H. Haber, Management. Zarys zarządzania mata firma, Wydawnictwo Profesjonalnej Szkoły Biznesu, Kraków 1993, s. 214.

2 Zob. L. Zbiegień-Maciąg i in., Zarzadzanie personelem w firmie, Wydawnictwo Akademii Górniczo-Hutniczej, Kraków 1996, s. 123.

${ }_{3}$ Zob. B. Gliński, B. R. Kuc (red.), Podstawy zarzadzania organizacjami, Państwowe Wydawnictwo Ekonomiczne, Warszawa 1990, s. 196; B. R. Kuc, Zarzadzanie doskonate, Wydawnictwo „Oskar-Master of Biznes”, Warszawa 1999, s. 212-213. 
irracjonalność. Należało zatem go unikać. Uważano, że powodem konfliktu są błędy kierownictwa w zarządzaniu firmą, a także brak otwartości i wzajemnego zaufania między ludźmi oraz niedostateczna komunikacja. Zgodnie $\mathrm{z}$ tradycyjnym poglądem na rolę konfliktu, konflikt przeszkadza w efektywnym funkcjonowaniu organizacji ${ }^{4}$, sprawia, że następuje pogorszenie relacji interpersonalnych, co prowadzi do dezintegracji załogi. Niekorzystne aspekty konfliktów ujawniają się zwłaszcza w sytuacji konfliktów przedłużających się i wyniszczających pracowników. Negatywne konsekwencje konfliktów mogą dotykać: jego stron, innych osób pośrednio związanych ze sprawą konfliktową lub całego przedsiębiorstwa. W związku z tym, optymalna efektywność organizacji wymaga likwidacji konfliktu ${ }^{5}$.

Aktualnie twierdzi się, że konflikt jest nieunikniony, a nawet konieczny. Może on bowiem w różnym stopniu przyczynić się do wzrostu efektywności przedsiębiorstwa. Istnieją zarówno szkodliwe, jak i korzystne konflikty, dlatego nie jest już konieczne ich bezwzględne tłumienie i rozwiązywanie. Należy kierować nimi tak, aby zminimalizować ich szkodliwe aspekty i zmaksymalizować pozytywne. Obecne poglądy zakładają, że konflikt może doprowadzić do poprawy sytuacji przedsiębiorstwa, wprowadzenia w nim innowacji i zmian. Konflikt nie zawsze prowadzi do strat jednej ze stron, a nawet może przynieść korzyści wszystkim zaangażowanym podmiotom. Współczesne poglądy na temat konfliktu mówią o tym, że zbyt mała ich ilość prowadzi do stagnacji, natomiast konflikt niekontrolowany grozi chaosem. Zatem konflikt nie jest niebezpieczny, lecz niebezpieczne jest błędne nim pokierowanie i wybór nieodpowiedniej metody jego rozwiązania ${ }^{6}$. Wczesne zauważenie konfliktu umożliwia podjęcie działań zmierzających do właściwego nim pokierowania i szybkiego jego rozwiązania. Tak więc, już sam konflikt w swej istocie może doprowadzić do integracji lub dezintegracji załogi, a wybór metody jego rozwiązania niewątpliwie przyczynia się do pogłębienia i utrwalenia zaistniałych relacji interpersonalnych.

Integracja załogi (pracownicza) jest rozumiana jako stan postaw i zachowań pracownika wskazujących na jego zespolenie z przedsiębiorstwem, jego celami działania, kierownictwem, zespołami pracowniczymi, rodzajem wykonywa-

${ }^{4}$ Zob. i por. D. Buchanan, A. Huczyński, Organizational behaviour, Wydawnictwo Prentice Hall, Glasgow 1997, s. 634-635; B. R. Kuc, op. cit., s. 214; S. P. Robbins, Zachowania w organizacji, Polskie Wydawnictwo Ekonomiczne, Warszawa 1998, s. 292; W. Bańka, Zarzadzanie personelem w przedsiębiorstwie, Wydawnictwo Adam Marszałek, Toruń 1998, s. 141.

${ }_{5}$ Zob. i por. K. Balawajder, Komunikacja. Konflikty. Negocjacje w organizacji, Wydawnictwo Uniwersytetu Śląskiego, Katowice 1998, s. 64; D. Buchanan, A. Huczyński, op. cit., s. 634-635; B. R. Kuc, op. cit., s. 214; S. P. Robbins, op. cit., s. 292; W. Bańka, op. cit., s. 141.

${ }_{6}^{6}$ Zob. B. R. Kuc, op. cit., s. 216; R. A. Webber, Zasady zarzqdzania organizacjami, Państwowe Wydawnictwo Ekonomiczne, Warszawa 1990, s. 435. 
nej pracy, zadaniami stawianymi pracownikom. Zespolenie wynika $\mathrm{z}$ osobistego przekonania pracownika, że dzięki przedsiębiorstwu będzie on zaspakajał własne potrzeby i realizował osobiste cele. Integracja pracownicza to także proces kształtowania się postaw i zachowań pracownika o charakterze integracyjnym (proces pogłębiania się $\mathrm{w}$ świadomości pracownika poczucia zespolenia $\mathrm{z}$ przedsiębiorstwem). Im wyższy stopień integracji pracowniczej, tym więcej korzystnych działań pracownika mających wpływ na przedsiębiorstwo jako całość (np.: wysoka wydajność pracy, zdyscyplinowanie, troska o mienie przedsiębiorstwa) ${ }^{7}$.

Dezintegracja pracownicza to sytuacja, gdy postawy i zachowania pracownika są oparte na założeniu, że nie będzie miał on możliwości realizacji indywidualnych celów w danym przedsiębiorstwie. Przy niskim stopniu dezintegracji załogi pracownik pozostaje $\mathrm{w}$ przedsiębiorstwie, ale szuka nieformalnych sposobów realizowania własnych celów. Przy wysokim stopniu dezintegracji pracownik może zdecydować się na rezygnację $\mathrm{z}$ pracy $\mathrm{w}$ danym przedsiębiorstwie ${ }^{8}$.

Ważnym zadaniem kierownictwa w każdym przedsiębiorstwie jest tworzenie warunków i szukanie czynników integrujących i neutralizowanie czynników dezintegrujących załogę. W przypadku, gdy w przedsiębiorstwie będą miały miejsce sytuacje konfliktowe jednym z czynników mających wpływ na proces integracji pracowniczej jest wybór odpowiedniej metody ich rozwiązywania.

Celem artykułu jest ukazanie związku między metodami rozwiązywania konfliktów w przedsiębiorstwie a integracją pracowniczą. Realizację tego celu umożliwi krótki przegląd podstawowych tradycyjnych i nowoczesnych metod rozwiązywania konfliktów.

\section{ETAPY ROZWIAZZYWANIA KONFLIKTÓW}

Niekontrolowane konflikty mogą doprowadzić do negatywnych następstw zarówno dla przedsiębiorstwa, jak i jego pracowników. Dlatego kadra kierownicza nie może być obojętna wobec konfliktów i powinna próbować je rozwiązywać.

Niezależnie od metody, proces rozwiązywania konfliktów składa się z kilku etapów.

W pierwszym etapie rozwiązywania konfliktów sprzeczności między stronami prowadzą początkowo do chęci ucieczki lub rezygnacji jednego lub obu

\footnotetext{
7 Zob. Encyklopedia organizacji i zarzadzania, PWE, Warszawa 1981, s. 173-174.

8 Ibidem, s. 96.

9 Zob. W. Bańka, op. cit., s. 149.
} 
uczestników konfliktu. Takie rozwiązanie nie zawsze jest jednak dla wszystkich zadowalające co sprawia, że po pewnym czasie dochodzi do walki ${ }^{10}$.

Walka to drugi etap rozwiązywania problemów. Strony przeciwstawiają się wówczas sobie i próbują dowieść swoich racji, chcą zniszczyć przeciwnika, minimalizując jednocześnie własne straty. Okazuje się często, że nie jest to łatwe $\mathrm{i}$ nie przynosi pełnej satysfakcji ${ }^{11}$. W tym momencie można sobie zdać sprawę, jak ważne jest umiejętne pokierowanie sytuacją konfliktową. Kadra kierownicza w zależności od okoliczności próbuje zastosować taktykę zapobiegania dalszej eskalacji konfliktu lub podjąć działania, których celem będzie rozwiązanie konfliktu ${ }^{12}$.

Sedno kolejnego etapu rozwiązywania konfliktów stanowi określenie problemu i rozpoznanie jego przyczyn. Trzeba wówczas zbadać na czym polega konflikt. Strony muszą ustalić co w postępowaniu partnera przyczyniło się do jego powstania konfliktu. Szczerze rozmawiając muszą stwierdzić jakie zachowania przeciwnika są nie do zaakceptowania przez każdą ze stron. Chcąc wyodrębnić przyczyny trzeba wziąć pod uwagę tylko te wydarzenia, które spowodowały, że konflikt się pojawił ${ }^{13}$.

Rozeznanie problemu pozwala na przejście do następnego etapu kierowania konfliktami, jakim jest próba znalezienia rozwiązań. Partnerzy konfliktu ustalają wówczas cele, do których dążą i sposób postępowania, który ma doprowadzić do rozstrzygnięcia sporu. Strony zmierzają do wyodrębnienia szeregu rozwiązań, co ułatwia dokonanie właściwego wyboru ${ }^{14}$.

Ocena i wybór rozwiązania stanowią kolejną część procesu kierowania konfliktami. Na wszystkie rozwiązania patrzy się wówczas z punktu widzenia skutków, jakie niosą dla obu stron. Wybiera się takie, które będzie zadowalało wszystkich, co pomoże w ich dalszej współpracy ${ }^{15}$.

Ostatnim etapem rozwiązywania konfliktów jest ich rozładowanie. Następuje wówczas wprowadzenie wybranego rozwiązania w życie, pojawiają się zmiany organizacyjne, znikają nieporozumienia, a potrzeby stron zostają zaspokojone ${ }^{16}$.

${ }_{10}$ Zob. H. Bieniok i zespół, Metody sprawnego zarządzania, Agencja Wydawnicza „Placet”, Warszawa 1997, s. 239.

11 Ibidem.

${ }_{12}$ Zob. J. Szczupaczyński, Anatomia zarzq̨dzania organizacja, Wydawnictwo Międzynarodowej Szkoły Menedżerów, Warszawa 1998, s. 192.

${ }_{13}$ Zob. L. Grzesiuk i in., Umiejętności menedżera. Psychologia stosowana dla menedżerów, Wydawnictwo Wyższej Szkoły Handlu i Prawa im. Ryszarda Łazarskiego, Warszawa 2001, s. $164-165$.

${ }^{14}$ Ibidem.

${ }^{15}$ Ibidem.

${ }^{16}$ Por. W. Kieżun, Sprawne zarządzanie organizacja, Wydawnictwo Szkoły Głównej Handlowej, Warszawa 1997, s. 373 i 387. 
„Każdy konflikt jest jedyny w swoim rodzaju, dlatego trudno jest znaleźć uniwersalne rozwiązanie dla wszystkich sytuacji konfliktowych"17. Ogólnie wszystkie sposoby rozwiązywania konfliktów można podzielić na tradycyjne i nowoczesne ${ }^{18}$. Istnieje wiele czynników mających wpływ na wybór metody rozwiązywania konfliktów. Należy do nich zaliczyć m.in.: kontekst sytuacyjny, kwalifikacje osób rozstrzygających, typ konfliktu, dostępność dóbr i środków $^{19}$. Podczas dokonywania wyboru metody rozwiązywania konfliktów istotne jest także spojrzenie stron biorących w nich udział na następstwa jakie za sobą niosą, w tym także na proces integracji pracowniczej.

\section{TRADYCYJNE METODY ROZWIAZZYWANIA KONFLIKTÓW}

„W podejściu tradycyjnym dominuje przekonanie, że konflikt zwykle kończy się zwycięstwem jednej ze stron (zasada wygrany-przegrany)”20.

Najbardziej znane tradycyjne techniki rozwiązywania konfliktów to:

- unikanie (wycofywanie się, ucieczka);

- odwlekanie;

- łagodzenie (dostosowywanie się, pokojowe współistnienie);

- wymuszanie (rywalizacja, dominacja);

- zasada większości;

- ingerencja trzeciej osoby.

Unikanie polega na rezygnacji z zajmowania się konfliktem. Zaprzecza się wówczas, że konflikt istnieje. Przybiera on wówczas postać ukrytą. Unikanie charakteryzuje się niewielkim ukierunkowaniem na realizację własnych potrzeb, jak również osiągnięcie celów innych ludzi zaangażowanych w konflikt. Taki styl kierowania konfliktami wybierają osoby, które źle znoszą napięcie emocjonalne lub doświadczyły wcześniej nieudanych prób stosowania innych stylów. Pozostają one wtedy neutralne lub ignorują przedmiot sporu mając nadzieję na to, że sytuacja z czasem się wyjaśni sama ${ }^{21}$. Ucieczka jest skuteczna w przypadku spraw mało ważnych lub gdy strony konfliktu nie wykazują chęci porozumienia się ${ }^{22}$. Nie jest to $z$ całą pewnością metoda mogąca służyć integracji załogi.

17 H. Bieniok i zespół, op. cit., s. 240.

18 Ibidem, s. 240.

19 Zob. B. R. Kuc, op. cit., s. 237.

${ }^{20}$ Ibidem.

${ }^{21}$ Zob. L. Grzesiuk i in., op. cit., s. 161.

${ }^{22}$ Zob. L. Zbiegień-Maciąg i in., op. cit., s. 128. 
Odwlekanie to tradycyjnie stosowana, ale najczęściej nieskuteczna metoda rozwiązywania konfliktów. W istocie rzeczy odwlekanie może stać się sposobem na ułatwienie rozstrzygnięcia sporu. Oczekuje się, że czas pomoże w rozwiązaniu problemu. Następują wówczas zmiany w środowisku, stygną emocje, strony są lepiej przygotowane do rozmów. Niestety nie zawsze odroczenie decyzji prowadzi do pomyślnego zakończenia konfliktu. Zdarza się, że po pewnym czasie następuje jego zaognienie, co grozi dezintegracją załogi. Odwlekanie stanowi skuteczną metodę rozwiązywania konfliktów w sytuacji, gdy w przedsiębiorstwie mają nastąpić zmiany personalne. Przykładem może być odejście jednej ze stron konfliktu na emeryturę lub do innej instytucji, czy też objęcie przez nią innego stanowiska ${ }^{23}$.

Łagodzenie przejawia się $\mathrm{w}$ rezygnacji $\mathrm{z}$ realizacji własnych interesów i pragnień przez jedną ze stron, przy równoczesnym dążeniu do zaspokojenia potrzeb partnera. Osoby o tym podejściu są gotowe poświęcić swój cel dla utrzymania dobrych kontaktów $z$ drugą stroną ${ }^{24}$. Niestety spychanie na dalszy plan osobistych celów uniemożliwia tworzenie więzi społecznych i nie jest czynnikiem sprzyjającym integracji załogi. Strategia dostosowywania się jest wykorzystywana, gdy przeciwnik jest postrzegany jako osoba silniejsza lub w przypadku, gdy taktyka jest ukierunkowana na to, że w przyszłości druga strona odwzajemni się tym samym ${ }^{25}$.

Wymuszanie jest wyrazem bardzo silnego dążenia jednej ze stron do zaspokojenia własnych potrzeb lub osiągnięcia określonego celu, przy równoczesnym lekceważeniu interesów drugiej strony. Nie ma działań skierowanych na dokonanie wewnętrznej spójności między członkami załogi, a więc nie ma przesłanek do tego, aby spodziewać się integracji pracowniczej. Podłożem takiego zachowania jest założenie wygranej za wszelką cenę. Jest to sytuacja, w której najbardziej uwidacznia się wygrany i przegrany. Wygrywa osoba silniejsza stosująca różne formy walki ${ }^{26}$. Rywalizacja jest stosowana w przypadku, gdy istotne jest szybkie, zdecydowane działanie, a konflikty dotyczą ważnych, wymagających wdrożenia niepopularnych decyzji, zagadnień. Tego rodzaju strategia może być użyteczna przy rozwiązywaniu często powtarzających się konfliktów między stronami nie rokujących szans na polubowne porozumie-

${ }^{23}$ Zob. S. Stachak, M. Świtłyk, Teoria zarządzania przedsiębiorstwami rolniczymi, Wydawnictwo „Książka i Wiedza”, Warszawa 1995, s. 213-214.

${ }^{24}$ Zob. A. Pocztowski, Zarzadzanie zasobami ludzkimi, Oficyna Wydawnicza „Antykwa”, Kraków 1998, s. 286.

${ }^{25}$ Zob. i por. S. P. Robbins, op. cit., s. 313; J. R. Gordon, Organizational behavior. A diagnostic approach, Wydawnictwo Prentice Hall, New Jersey 1999, s. 282.

${ }^{26}$ Zob. Z. Rummel-Syska, Konflikty organizacyjne. Ujęcie mikrospoteczne, PWN, Warszawa 1990, s. 70-71. 
nie się ${ }^{27}$. Wymuszanie jest często stosowane przez bezpośrednich zwierzchników. W sytuacjach ekstremalnych postanawiają oni rozdzielić strony konfliktu np. przez przeniesienie ich do różnych działów przedsiębiorstwa, a nawet zwolnienia $\mathrm{z}$ pracy ${ }^{28}$.

Zasada większości opiera się na założeniu, że istnieje pewna grupa ludzi, których cele i potrzeby są spójne. Sprawiają oni, że ludzie ci opowiadają się za takim samym rozwiązaniem. Głosowanie prowadzi do znalezienia korzystnego rozwiązania z punktu widzenia większości uczestników konfliktu. Zasada większości jest skuteczna tylko wtedy, gdy strony konfliktu uznają tę strategię za słuszną. Jeżeli jedna ze stron będzie ciągle przegrywać poczuje się ona bezsilna i sfrustrowana. Człowiek jest sfrustrowany, gdy nie może osiągnąć postawionego przez siebie celu, ale jednocześnie nie może przestać do niego dążyć. Sytuacja taka może doprowadzić do wzmożenia konfliktu i pogłębić proces dezintegracji pracowniczej ${ }^{29}$.

Ingerencja trzeciej osoby jest stosowana wówczas, gdy rozmowy między stronami do niczego nie prowadzą. Strony są w ciągłym konflikcie i nie potrafią samodzielnie rozstrzygnąc sporu. Właśnie wtedy skutecznym rozwiązaniem konfliktu może stać się narzucenie woli trzeciej strony. Werdykt ten jest na ogół nieodwołalny ${ }^{30}$. Jeśli rozwiązanie proponowane przez osobę trzecią jest zbliżone do oczekiwań jednej ze stron konfliktu, wówczas nie sprzyja to procesowi integracji pracowniczej.

Wszystkie te metody wpływania na konflikt mogą być wykorzystywane w przypadku niezbyt istotnych problemów ze względu na ich podstawową wadę, jaką jest nie zajmowanie się przyczynami powstawania nieporozumieñ $^{31}$. Wszystkie te metody w mniejszym lub w większym stopniu prowadzą do dezintegracji pracowniczej.

\section{NOWOCZESNE METODY ROZWIĄZYWANIA KONFLIKTÓW}

Chcąc rozwiązać poważne problemy, dotyczące dużej grupy ludzi i mające wpływ na całe przedsiębiorstwo, nie można odkładać ich na później. Należy wówczas stosować konstruktywne strategie, które mają doprowadzić do pozy-

27 Zob. S. P. Robbins, op. cit., s. 313.

${ }^{28}$ Zob. L. Zbiegień-Macią, W. Pawnik, Zarządzanie organizacja, Wydawnictwo Akademii Górniczo-Hutniczej, Kraków 1995, s. 62.

${ }^{29}$ Zob. J. A. F. Stoner, Ch. Wankel, Kierowanie, Polskie Wydawnictwo Ekonomiczne, Warszawa 1996, s. 340.

30 Zob. L. Zbiegień-Maciąg, W. Pawnik, op. cit., s. 62.

${ }^{31}$ Zob. i por. J. Szczupaczyński, op. cit., s. 193; J. R. Gordon, op. cit., s. 282. 
tywnego myślenia o sytuacji konfliktowej i sprawić, że wszyscy skoncentrują się na wzajemnej współpracy zmierzającej do wyeliminowania konfliktu ${ }^{32}$. Do najczęściej spotykanych metod nowoczesnego kierowania konfliktami należą:

- kompromis;

- uzgadnianie;

- spotkanie konfrontacyjne;

— ustanowienie nadrzędnych celów;

- ujawnienie wspólnego interesu;

- przetarg;

- negocjacje;

- mediacja;

- arbitraż;

- decyzje hierarchiczne;

- strategia apelacyjna;

- strategia rekonstrukcji systemu;

- sesja wymiany wizerunków.

Kompromis to taka postawa, która opiera się na założeniu, że każda ze stron częściowo zaspokaja własne interesy i częściowo zaspokaja interesy partnera. Każdy korzysta i traci podczas realizacji określonego celu ${ }^{33}$. Kompromis jest często stosowaną metodą rozwiązywania konfliktów. Wykorzystuje się go np. w sytuacji, gdy ilość zasobów jest ograniczona, a są one pożądane przez dwie lub więcej osób ${ }^{34}$. Możliwość realizacji celów każdej ze stron konfliktu pobudza proces integracji załogi.

Strategia uzgadniania polega na znalezieniu najlepszego rozwiązania problemu przez strony konfliktu. Uczestnicy konfliktu nie zabiegają wówczas o zaspokojenie wyłącznie własnych potrzeb, lecz chcą doprowadzić do zadowolenia wszystkich, co służy zespoleniu zbiorowości i prowadzi do integracji pracowniczej. Grupowe uzgadnianie stanowi skuteczną metodę rozwiązywania problemów. Jest ono często lepsze niż indywidualne dążenie do ich rozstrzygnięcia. Ważne jest jednak to, aby szukać najlepszego rozwiązania, a nie tylko zmierzać do szybkiego zakończenia konfliktu ${ }^{35}$.

Spotkanie konfrontacyjne ma na celu znalezienie wyjścia z konfliktu korzystnego z punktu widzenia obu stron. Podczas konfrontacji strony otwarcie przedstawiają własne poglądy. Zwracają one uwagę na przyczyny konflik-

${ }^{32}$ Zob. L. Zbiegień-Maciąg, W. Pawnik, op. cit., s. 63.

33 Por. L. Grzesiuk i in., op. cit., s. 162; D. Fisher, Communication in organizations, Wydawnictwo West Publishing Company, Minneapolis-St. Paul 1993, s. 378.

${ }_{34}$ Zob. B. R. Kuc, op. cit., s. 239.

${ }^{35}$ Zob. J. A. F. Stoner, Ch. Wankel, op. cit., s. 341. 
tu i szukają metod ich rozwiązania. Skupiają się na sprawach ważnych, a nie drugorzędnych. Aby rozwiązać konflikt muszą przenieść akcent sporu z osoby na sprawę. Nie mogą być wrogo nastawione do partnera dyskusji, bo postrzeganie go jako przeciwnika zamyka drogę do porozumienia. Mądre przygotowanie dyskusji na spotkaniu konfrontacyjnym gwarantuje pomyślne rozwiązanie problemu i prowadzi do integracji załogi ${ }^{36}$.

Ustanowienie nadrzędnych celów może być także metodą rozwiązywania konfliktów. Dążenie do celu nadrzędnego prowadzi bowiem do integracji zespołu i odwrócenia uwagi stron konfliktu od sprzecznych dążeń. Jego osiągnięcie przynosi pracownikom szereg korzyści, co motywuje do zaniechania konfliktu i rozpoczęcia współpracy ${ }^{37}$.

Ujawnienie wspólnego interesu np.: celu, obrony przed zagrożeniem czy możliwości zaspokojenia potrzeb to kolejna technika nowoczesnego rozwiązywania konfliktów, która jest uznawana za obiecującą i jedną z najlepszych w zastosowaniu. Wspólne interesy, zagrożenie i odpowiedzialność są silnym elementem integrującym strony będące $\mathrm{w}$ konflikcie i często prowadzą do zamiany konfliktu na współpracę ${ }^{38}$.

Przetarg polega na wymianie ofert i wzajemnych ustępstw, co pomaga w znalezieniu rozwiązania konfliktu akceptowalnego przez obie jego strony i pobudza proces integracji pracowniczej. Jego celem jest zakończenie sporów związanych z podziałem ograniczonych zasobów, podpisaniem ostatecznego porozumienia czy też ustaleniem warunków pracy. Obie strony za pośrednictwem oficjalnie wybranych reprezentantów świadomie uczestniczą w przetargu postępując zgodnie $\mathrm{z}$ przyjętymi przepisami. Taki sposób radzenia sobie z konfliktem jest korzystny zwłaszcza wówczas, gdy siły stron równoważą się a także, gdy istnieje wiele różnych możliwości rozstrzygnięć satysfakcjonujących każdego z uczestników sporu ${ }^{39}$.

„Negocjacje są procesem, w którym wzajemne oddziaływanie dwóch stron za pośrednictwem rozmaitych kanałów komunikacji zmierza do wspólnego rozwiązania konfliktu" ${ }^{40}$. Można wyróżnić trzy sposoby prowadzenia negocjacji w warunkach konfliktu:

- negocjacje przez akty unikowe;

- negocjacje przez akty separacyjne;

- negocjacje przez akty integracyjne ${ }^{41}$.

${ }^{36}$ Zob. H. Bieniok i zespół, op. cit., s. 242-243.

37 Zob. J. Szczupaczyński, op. cit., s. 196.

38 Zob. B. R. Kuc, op. cit., s. 239.

39 Zob. J. Szczupaczyński, op. cit., s. 194; Z. Rummel-Syska, op. cit., s. 123.

${ }^{40}$ J. A. F. Stoner i in., Kierowanie, Polskie Wydawnictwo Ekonomiczne, Warszawa 1997, s. 521.

${ }^{41}$ Zob. L. H. Haber, op. cit., s. 222-224. 
Prowadząc negocjacje przez akty unikowe zaprzecza się, że nastąpił konflikt i sprowadza się go do kwestii drugorzędnych np.: dąży się do zmiany tematu konfliktowego w wątki bardziej ogólne, zmierza się do uabstrakcyjnienia sporu poprzez wprowadzenie kwestii bardzo odległych lub żartem próbuje się wprowadzić inny poziom rozmowy ${ }^{42}$. Tego rodzaju negocjacje nie są $z$ pewnością zbyt skuteczną metodą rozwiązywania konfliktów, ale nie wykluczają one integracji pracowniczej.

Negocjacje przez akty separacyjne polegają na okazywaniu niechęci do wspólnego działania. Są one najbardziej negatywną metodą prowadzenia rozmów. W ich wyniku konflikty często nie znajdują rozwiązania, a nawet dochodzi do ich pogłębienia. W takiej sytuacji konieczna jest szybka reakcja stron zmierzająca do zmiany sposobu prowadzenia rozmów i rozładowania atmosfery $^{43}$.

Negocjacje przez akty integracyjne są przykładem konstruktywnej reakcji na konflikt. Polegają one na dążeniu do pogodzenia zwaśnionych stron i budowaniu między nimi więzi ${ }^{44}$.

Podczas dążenia do rozwiązania określonego konfliktu mogą być stosowane wszystkie trzy sposoby negocjacji i w przypadku właściwego ich wykorzystania będą one przynosiły pozytywne skutki ${ }^{45}$. Najskuteczniejszą jednak metodą rozwiązywania konfliktów prowadzącą do zespolenia załogi są negocjacje przez akty integracyjne. Nie możemy jednoznacznie stwierdzić, że zastosowanie dwóch pozostałych technik negocjacji pobudzi proces integracji załogi.

Jeśli w wyniku prowadzenia negocjacji następuje zaostrzenie konfliktu konieczna staje się interwencja osoby trzeciej (mediatora) w proces poszukiwania satysfakcjonującego obie strony rozwiązania. Mediator zawdzięcza swoją pozycję przyzwoleniu obydwu stron. Nie ma on władzy formalnej i nie może narzucać rozwiązań. Jego zadaniem jest: ułatwienie komunikacji między stronami, łagodzenie napięć i emocji, podpowiadanie ewentualnych rozwiązań ${ }^{46}$. „Warunkiem efektywnej mediacji jest bezstronność i unikanie przejmowania od stron konfliktu głównego wysiłku wypracowania porozumienia" ${ }^{47}$. W związku z tym, że rozwiązanie konfliktu proponowane przez mediatora powinno prowadzić do zadowolenia wszystkich uczestników sporu, przyczyni się ono do pojawienia się więzi społecznej i spójności grupy, czyli pobudzi proces integracji pracowniczej.

\footnotetext{
42 Ibidem, s. 222-223.

${ }^{43}$ Ibidem, s. 223.

44 Ibidem, s. 223-224.

45 Ibidem, s. 224.

46 Zob. i por. J. Szczupaczyński, op. cit., s. 194; D. Buchanan, A. Huczyński, op. cit., s. 658-659.

47 Zob. J. Szczupaczyński, op. cit., s. 194.
} 
Arbitraż jest metodą regulowania konfliktów podobną do procedury mediacyjnej. Istnieje między nimi jedna zasadnicza różnica. Arbiter w przeciwieństwie do mediatora ma prawo narzucić stronom konfliktu określone przez siebie ustalenia. Skuteczność arbitrażu jest uzależniona od tego, czy wprowadzone przez arbitra rozwiązanie przyniesie stronom na dłuższą metę satysfakcję, a także od środków stosowanych w celu wymuszenia realizacji ustaleń arbitrażowych ${ }^{48}$. Jeśli rozwiązanie problemu zaproponowane przez arbitra uwzględni cele stron konfliktu, to arbitraż może być skuteczną metodą rozwiązywania sporów prowadzącą do integracji załogi.

Decyzje hierarchiczne zakładają możliwość skorzystania z pomocy przełożonego w przypadku pojawienia się sytuacji konfliktowej. Kierownik jako osoba postawiona wyżej w hierarchii służbowej może rozstrzygnąć konflikt lub wyznaczyć komisje rozjemcze. Przełożony nie powinien równocześnie dążyć do wymuszenia oczekiwanych przez niego zachowań. Skuteczność tej metody rozwiązywania konfliktów jest uzależniona od: postawy przełożonego, jego wiedzy, mądrości, zdrowego rozsądku i sprawiedliwości. Może być ona wykorzystywana tylko wówczas, gdy ludzie mają zaufanie do hierarchii ${ }^{49}$. Właściwe pokierowanie konfliktem przez przełożonego i wybór rozwiązania satysfakcjonującego wszystkich uczestników sporu wzbudzi poczucie przynależności do grupy, co uruchomi proces integracji pracowniczej.

Strategia apelacyjna jest wykorzystywana w przypadku niezadowolenia stron z wydanych decyzji. W takiej sytuacji strony odwołują się do wyższych instytucji takich jak sądy pracy, czy też organy apelacyjne. Tryb odwołań jest uregulowany przepisami dotyczącymi prawa pracy ${ }^{50}$. Dopiero decyzje władz wyższej instancji dają szansę na znalezienie rozwiązań satysfakcjonujących wszystkich uczestników sporu, co może przyczynić się do rozpoczęcia procesu integracji załogi.

Strategia rekonstrukcji systemu znajduje swoje zastosowanie w sytuacjach, których podłożem konfliktu jest wadliwa struktura systemu organizacyjnego. Strategia ta polega na takiej zmianie systemu, która będzie sprzyjać ograniczeniu powstawania konfliktów. Może się to odbywać poprzez: rotację personelu, przedzielenie buforem (może nim być człowiek, który nie zagraża żadnej ze stron, potrafi wysłuchać pretensji, jest odporny na presje i próby przekupstwa, umie znosić ataki i groźby), scalanie zadań ${ }^{51}$. Tak więc, zmiany organi-

${ }^{48}$ Zob. i por. B. Gliński, B. R. Kuc (red.), op. cit., s. 202; D. Buchanan, A. Huczyński, op. cit., s. 659-660.

${ }^{49}$ Zob. L. Zbiegień-Maciąg i in., op. cit., s. 129.

${ }^{50}$ Zob. Cz. Linczowski, Organizacja, zarzadzanie i elementy marketingu, Wydawnictwo Politechniki Świętokrzyskiej, Kielce 1999, s. 303.

${ }^{51}$ Zob. L. Zbiegień-Maciąg i in., op. cit., s. 129. 
zacyjne polegają na takim rozdzieleniu stron, które sprawia, że nie mają one możliwości szkodzić sobie nawzajem. Ewentualne przeniesienia pracowników dają szansę na znalezienie się w takim środowisku, które będzie sprzyjało integracji. Zmiany systemu sprowadzają się także do takiego łączenia zadań stawianych przed pracownikami, które wywoła poczucie zbieżności celów indywidualnych z celami przedsiębiorstwa jako całości, co jest ważnym elementem integracji pracowniczej.

Sesja wymiany wizerunków służy budowaniu wzajemnego zaufania, bowiem jego brak przyczynia się do powstawania konfliktów. Każda ze stron sporu dowiaduje się jak jest postrzegana przez drugą. Wszyscy mają okazję do wyrażania własnych odczuć. Jeśli informacje są przekazywane w sposób otwarty i nie są one zniekształcane, strony konfliktu lepiej rozumieją swoje postawy, zachowania i motywy działania. Daje to szansę na dążenie do zbieżnych celów i poszukiwanie wspólnych rozwiązań, a tym samym przyczynia się do integracji załogi. Aby sesja przyniosła oczekiwane rezultaty konieczna jest dobra wola i dojrzałość emocjonalna uczestników ${ }^{52}$.

Nowoczesne metody kierowania konfliktami zakładają wykorzystywanie mniej szkodliwych sposobów rozładowywania napięć niż agresja i destrukcja. Ich podstawą jest pozytywne myślenie o sytuacji konfliktowej i dążenie do jej konstruktywnego rozwiązania, pobudzającego także proces integracji pracowniczej ${ }^{53}$.

\section{ZAKOŃCZENIE}

Podsumowując należy zauważyć, że z jednej strony konflikty mogą prowadzić do: nieusprawiedliwionej absencji, wzrostu skarg na warunki pracy, czy też zwiększonej fluktuacji. W rezultacie konflikty mogą znaleźć swoje odbicie w niszczeniu współpracy i zakłóceniach komunikacji między pracownikami. Konflikty mogą więc dezintegrować grupy, co może objawiać się występowaniem z nich jednostek i powstawaniem mniejszych, często nieformalnych zespołów.

Z drugiej zaś strony konflikty mogą przyczynić się do integracji załogi. Wzmacniają one więzi między pracownikami. Często dopiero w wyniku zaistnienia konfliktu zespół staje się silnie zintegrowaną grupą, w obrębie której występuje poczucie wzajemnej solidarności. W trakcie trwania konfliktu krystalizuje się struktura grupy, ujawniają się osoby przewodzące, eliminuje się jednostkowe nieporozumienia.

1 Zob. H. Bieniok i zespół, op. cit., s. 243.

${ }^{2}$ Zob. L. Zbiegień-Maciąg, W. Pawnik, op. cit., s. 65. 
Trzeba też pamiętać, że nie tylko sam fakt wystąpienia sytuacji konfliktowej, ale także odpowiedni dobór jej metody rozwiązywania wywiera istotny wpływ na proces integracji pracowniczej. Wybierając tradycyjne metody rozwiązywania konfliktów trzeba liczyć się z tym, że ich następstwem najczęściej będzie dezintegracja załogi, bowiem zakłada się w nich, iż konsekwencją sporu jest zysk jednej ze stron kosztem drugiej strony. W większości przypadków nowoczesne metody kierowania konfliktem wskazują, że nie muszą one przynosić strat jednej ze stron. Dobrze kierowany konflikt wywoła poczucie zbieżności celów działania, pozwoli osiągnąć korzyści wszystkim zainteresowanym stronom (niezależnie od zajmowanego stanowiska), co pobudzi proces integracji pracowniczej.

Ogólnie można powiedzieć, że właściwie przezwyciężone spory prowadzą do integracji załogi, sytuacja wszystkich zainteresowanych osób poprawia się, a równowaga ustala się na nowym, wyższym poziomie.

\section{BIBLIOGRAFIA}

Balawajder K., Komunikacja. Konflikty. Negocjacje w organizacji, Wydawnictwo Uniwersytetu Śląskiego, Katowice 1998.

Bańka W., Zarządzanie personelem w przedsiębiorstwie, Wydawnictwo Adam Marszałek, Torun 1998.

Bieniok H. i zespó1, Metody sprawnego zarzadzania, Agencja Wydawnicza „Placet”, Warszawa 1997.

Buchanan D., Huczyński A., Organizational behaviour, Wydawnictwo Prentice Hall, Glasgow 1997.

Fisher D., Communication in organizations, Wydawnictwo West Publishing Company, Minneapolis-St. Paul 1993.

Gliński B., Kuc B. R. (red.), Podstawy zarzadzania organizacjami, Państwowe Wydawnictwo Ekonomiczne, Warszawa 1990.

Gordon J. R., Organizational behavior. A diagnostic approach, Wydawnictwo Prentice Hall, New Jersey 1999.

Grzesiuk L. i in., Umiejętności menedżera. Psychologia stosowana dla menedżerów, Wydawnictwo Wyższej Szkoły Handlu i Prawa im. Ryszarda Łazarskiego, Warszawa 2001.

Haber L. H., Management. Zarys zarzadzania mata firma, Wydawnictwo Profesjonalnej Szkoły Biznesu, Kraków 1993.

Kieżun W., Sprawne zarządzanie organizacją, Wydawnictwo Szkoły Głównej Handlowej, Warszawa 1997.

Kuc B. R., Zarzadzanie doskonate, Wydawnictwo „Oskar-Master of Biznes”, Warszawa 1999.

Linczowski Cz., Organizacja, zarzqdzanie i elementy marketingu, Wydawnictwo Politechniki Świętokrzyskiej, Kielce 1999. 
Pocztowski A., Zarzadzanie zasobami ludzkimi, Oficyna Wydawnicza „Antykwa”, Kraków 1998.

Robbins S. P., Zachowania w organizacji, Polskie Wydawnictwo Ekonomiczne, Warszawa 1998.

Rummel-Syska Z., Konflikty organizacyjne. Ujęcie mikrospoteczne, PWN, Warszawa 1990.

Stachak S., Świttyk M., Teoria zarzadzania przedsiębiorstwami rolniczymi, Wydawnictwo „Książka i Wiedza”, Warszawa 1995.

Stoner J. A. F. i in., Kierowanie, Polskie Wydawnictwo Ekonomiczne, Warszawa 1997.

Stoner J. A. F., Wankel Ch., Kierowanie, Polskie Wydawnictwo Ekonomiczne, Warszawa 1996.

Szczupaczyński J., Anatomia zarządzania organizacja, Wydawnictwo Międzynarodowej Szkoły Menedżerów, Warszawa 1998.

Webber R. A., Zasady zarzadzania organizacjami, Państwowe Wydawnictwo Ekonomiczne, Warszawa 1990.

Zbiegień-Maciąg L. i in., Zarzadzanie personelem w firmie, Wydawnictwo Akademii Górniczo-Hutniczej, Kraków 1996.

Zbiegień-Maciąg L., Pawnik W., Zarzadzanie organizacja, Wydawnictwo Akademii Górniczo-Hutniczej, Kraków 1995.

\title{
METODY ROZWIĄZYWANIA KONFLIKTÓW W PRZEDSIĘBIORSTWIE A INTEGRACJA PRACOWNICZA
}

\section{STRESZCZENIE}

Celem artykułu jest ukazanie związku między metodą rozwiązywania konfliktów w przedsiębiorstwie i integracją pracowniczą. Dobór metody rozwiązywania konfliktów wywiera istotny wpływ na proces integracji pracowniczej. Wybierając tradycyjne metody ich rozwiązywania trzeba liczyć się z tym, że następstwem będzie dezintegracja załogi, bowiem zakłada się w nich, iż konsekwencją sporu jest zysk jednej ze stron kosztem drugiej strony. W większości przypadków nowoczesne metody kierowania konfliktem wskazują, że nie muszą one przynosić strat jednej ze stron. Dobrze kierowany konflikt wywoła poczucie zbieżności celów działania, pozwoli osiągnąć korzyści wszystkim zainteresowanym stronom, co pobudzi proces integracji pracowniczej.

\section{METHODS OF RESOLVING CONFLICT IN AN ENTERPRISE AND EMPLOYEES INTEGRATION}

\author{
SUMMARY
}

This article aims to show the relationship between the method of resolving conflicts in the company and employees integration. Selection methods of conflict reso- 
lution has a significant impact on employee integration process. Choosing traditional methods of conflict resolution must reckon with the fact that their consequence is the disintegration of the staff, because they assumed that the consequence of the dispute is the profit of one party over another party. In most cases, modern methods of conflict management suggests that conflicts do not have to bear the losses of one party. A well-managed conflict will trigger a sense of convergence of action and will allow all parties involved to achieve benefits, which will stimulate the integration of employees. 
